\title{
Editorial
}

\section{Innovating with ICTs in Content and Language Environments}

Innovando con las TIC en ambientes de contenido y lenguaje

Inovando com as TIC em ambientes de conteúdo e linguagem

Jermaine S. MCDOUGALD

orcid.org/0000-0002-2558-5178.

Universidad de La Sabana, Colombia.

jermaine.mcdougald@unisabana.edu.co 


\section{Introduction}

In recent years, information and communication technologies (ICTs) have played an increasingly key role in many contemporary societies. Offering challenges but also opportunities for education, such technologies can improve efficiency in the classroom and connect that classroom with the learner's wider world. The inclusion of ICTs in the classroom not only brings diversity to learning programs but forces teachers to rethink the delivery of their content and language goals. It has been shown that social interaction has a direct relation to the development of communicative skills and language learning (McDougald, 2009), but adding a few more ingredients-such as content and language integrated learning (CLIL)—can make the recipe for learning much more interesting.

With the ever increasing growth of the Internet, the diversity of learning programs continues to evolve in response to the changing demands of society (McDougald, 2013; Savage, 2010). In this scenario, ICTs have helped educators change their pedagogies to improve classroom practices for a foreign- or second-language learning scenarios (Abdullahi, 2013; Jimoyiannis \& Komis, 2007; Manaouchers, Tabatabaei, Gui, 2011; McDougald, 2013; Player-Koro, 2012). Yet, at the same time, educators may still neglect the very language needed to use those digital tools effectively, thereby placing additional strain and stress on the learning process. This can especially be the case when learners are trying to understand or manipulate elements such a platform, a dropdown menu or to otherwise engage with and-more importantly-make practical use of software interfaces for a variety of educational and/ or productive purposes. The language required dealing with ICT tools successfully can vary considerably but educators are often reluctant to invest time in "teaching" that language, for all that it may be some of the language their learners most need to survive and thrive in the knowledge-driven economies and societies of the $21^{\text {st }}$ century.

This neglect of content-oriented skills language-functional language-is found across the board (in the sciences, math, administration, etc.). There are many "soft skills" that are seldom considered when teaching either language or content—or even content and language 
together. Yet such skills, and the language needed to make use of them (which is often rich and full of opportunities for increased communication in the classroom) may make a profound difference in providing further access to learning of both language and content.

A CLIL approach can provide excellent opportunities for educators to prepare students for learning and mastering $21^{\text {st }}$-century skills (Deyrich \& Kari Stunnel, 2014; Wankel, 2012), which is why raising language awareness, exploiting CLIL, and making more effective educational uses of ICTs are increasingly relevant for every classroom. Learners need to be well versed in seven key areas, often referred to as the 7Cs: (1) critical thinking and problem solving; (2) creativity \& innovation; (3) collaboration, teamwork, and leadership; (4) cross-cultural understanding; (5) communication, information, and media literacy; (6) computing and ICT literacy; and (7) career and learning self-reliance (Abdullahi, 2013). A CLIL approach can offer a perfect learning environment in which to foster the 7Cs: (a) content brings the real world into the classroom, and (b) content provides a means for developing more advanced language proficiency (that can be transferred to academic contexts). Because the development of communicative skills and language learning requires social interaction (between teacher and students, amongst the students themselves, etc.), the inclusion of ICTs - via the Internet, the Web, social media, even (still!) email—offer additional support to communication both inside and outside the classroom. ICTs provide opportunities for interaction with others around the world through simulations, modeling, online/ virtual fieldtrips, and digital "pen pals", while through social media learners can access the latest on live and current events or even generate their own content. Although it has sometimes been objected that classroom uses of ICTs can limit the types and amounts of interaction taking place (Melor, Maimun, \& Chua, 2009), educational practices that foreground learning objectives, choosing ICT tools appropriate to those objectives (and not the other way around) offer extensive possibilities for customized and relevant learning (Bonnett, Mcfarlane, \& Williams, 1999; Fontecha, 2014; Hu \& McGrath, 2011; Melor et al., 2009). Moreover, ICT tools help learners realize opportunities to cross borders virtually, to embrace multiculturalism and multilingualism, and to develop as global citizens. 
Teaching in bi- and multilingual environments has driven teachers to become more creative and innovative in their classrooms. It is no longer enough to use the materials provided by textbooks or even the online supplementary materials that many publishers now provide. In recognizing the vast diversity in contemporary classrooms, we also recognize that such "stock" materials are too few and too slow to be developed, and that they cannot attend to all learners' needs. In this sense, it is more important than ever for teachers to know who their students are and how they learn. Such possibilities are a natural fit with the CLIL approach, in which collaboration and social interaction are recognized as essential components for successful learning (Mattheoudakis, Alexiou, \& Laskaridou, 2013).

\section{In this issue}

This issue of the Latin American Journal of Content and Language Integrated Learning (LACLIL, Vol. 10, No. 2, 2017) brings together five unique approaches to combining content and language through technologies, science, and self-assessment to address an array of learning issues at various levels of education. Ohlberger and Wegner (2017) start by exploring the possibility how subject-specific (biological) knowledge is influenced by biology-orientated content lessons at a grammar school in Germany, using a test and a control group. Their results revealed that there was a slightly higher knowledge gain in bilingual students as compared to the monolingual group. Castillo (2017), on the other hand, explores writing by using authentic scientific text mediated by ICTs. He also designed a syllabus that included digital tools that helped participants raise their awareness regarding importance of L2 when seeking information in scientific texts.

On a different note, Arteaga (2017) examines the process-genre approach, finding it effective in helping young EFL learners achieve the necessary writing goals. Similarly, Marenco (2017) assessed how peer tutoring and computer-mediated tasks affect students' spoken fluency, as well as motivation and confidence, through enhancing student-student interaction. Finally, García-Herreros, (2017) discusses an immersion learning model that unites Understanding by Design (UbD) with a 
$21^{\text {st }}$ century skills framework to integrate content from different areas and help Colombian students develop their English language skills.

It comes as no surprise that the CLIL approach continues to be at the forefront of $21^{\text {st }}$-century educational initiatives. Nevertheless, the articles in this issue of LACLIL remind us of the CLIL approach's versatility, providing practitioners and researchers with spaces to debate how classroom practices can be improved to bring learners a step closer to mastering $21^{\text {st }}$-century skills both inside and outside the classroom.

\section{References}

Abdullahi, H. (2013). The role of ICT in teaching science education in schools. International Letters of Social and Humanistic Sciences, 19(2011), 217-223. https://doi.org/10.18052/www.scipress.com/ILSHS.19.217

Arteaga, H. M. (2017). Using the process-genre approach to improve fourth-grade EFL learners' paragraph writing. Latin American Journal of Content \& Language Integrated Learning, 10(2), 217-244.

Bonnett, M., Mcfarlane, A., \& Williams, J. (1999). ICT in subject teaching: an opportunity for curriculum renewal? The Curriculum Journal, 10(3), 343-359. https://doi.org/10.1080/0958517990100303

Castillo, R. (2017). Changing the Course: Interpreting and Structuring Scientific Texts Aided by ICT. Latin American Journal of Content \& Language Integrated Learning, 10(2), 245-270.

Deyrich, M.-C., \& Stunnel, K. (2014). Language Education Models: New Issues and Challenges. Utrecht Studies in Language and Communication, (27). Retrieved from https://www.questia.com/library/journal/1P3-3296855931/language-teacher-education-models-new-issues-and

Fontecha, A. F. (2014). CALL syllabus integration through ICT-mediated tasks. Didáctica, Lengua Jy Literaura, 26, 147-168. https://doi.org/http:// dx.doi.org/10.5209/rev_DIDA.2014.v26.46835

García-Herreros, H. M. (2017). The road to bilingualism: Cases of success. Latin American Journal of Content \& Language Integrated Learning, 10(2), 297-307. 
Hu, Z., \& McGrath, I. (2011). Innovation in higher education in China: Are teachers ready to integrate ICT in English language teaching? Technology, Pedagogy and Education, 20(1), 41-59. https://doi.org/10.1080/14 75939X.2011.554014

Jimoyiannis, A., \& Komis, V. (2007). Examining teachers' beliefs about ICT in education: implications of a teacher preparation programme. Teacher Development, 11(2), 149-173. https://doi.org/10.1080/13664530701414779

Manaouchers, T., \& Gui, Y. (2011). The impact of technology on teaching and learning: lessons from research. In A. Mendez-Vilas (Ed.), Education in a Technological World: Communicating Current and Emerging Research and Technological Efforts (pp. 513-517). Badajoz: Formatex Research Center.

Marenco Dominguez, J. M. (2017). Peer-tutoring to foster spoken fluency in computer-mediated tasks. Latin American Journal of Content \& Language Integrated Learning, 10(2), 271-296.

Mattheoudakis, M., Alexiou, T., \& Laskaridou, C. (2013). To CLIL or not to CLIL? In N. Lavidas, T. Alexiou \& A.M. Sougari (Eds.): Major Trends in Theoretical and Applied Linguistics 3. Selected Papers from the 20th ISTAL (pp. 215-234). Retrieved from: https://content.sciendo.com/view/bo ok/9788376560915/10.2478/9788376560915.p13.xml

McDougald, J. S. (2009). The use of information and communication technology (ICT) in the EFL classroom as a tool to promote L2 (English) among non-native pre-service English teachers. University of Jaén. Retrieved from http://asian-efl-journal.com/thesis/2012/07/16/theuse-of-information-and-communication-technology-ict-in-the-eflclassroom-as-a-tool-to-promote-12-english-among-non-native-preservice-english-teachers/

McDougald, J. S. (2013). The use of new technologies among in-service Colombian ELT teachers. Colombian Applied Linguistic Journal, 15(2), 247-264.

Melor, M. Y., Maimun, A. L., \& Chua, P. L. (2009). Language learning via ICT: Uses, challenges and issues. WSEAS Transactions on Information Science and Applications, 6(9), 1453-1467.

Ohlberger, S., \& Wegner, C. (2017). Measuring the knowledge increase of eighth grade students in a bilingual biology unit. Latin American Journal of Content \& Language Integrated Learning, 10(2), 189-216. 
Player-Koro, C. (2012). Factors Influencing Teachers' Use of ICT in Education. Education Inquiry, 3(1), 93-108. https://doi.org/10.3402/edui. v3i1.22015

Savage, J. (2010). A survey of ICT usage across English secondary schools. Music Education Research, 12(1), 89-104. https://doi.org/10.1080/ 14613800903568288

Wankel, C. (2012). Educating Educators with Social Media. Development and Learning in Organizations: An International Journal, 26(3), E115-E116. http://dx.doi.org/10.1108/dlo.2012.08126caa.012 
